\title{
Decision-making, leadership and performance links in private education institutes
}

\author{
Nuri Gökhan Torlak \\ Department of Business Administration, \\ Faculty of Economics and Administrative Sciences, Doğus University, \\ Istanbul, Turkey, and \\ Ahmet Demir and Taylan Budur \\ Department of Business and Management, \\ Faculty of Economics and Administrative, Tishk International University, \\ Sulaimani, Iraq
}

\begin{abstract}
Purpose - This paper aims to investigate the relationships between participative decision-making, ethical leadership and leadership performance, which might make school leaders quit autocratic behavior and enhance their performance at private K12 schools in Iraq.

Design/methodology/approach - The researchers collected data through a questionnaire using a stratified sampling methodology from 207 educators of 10 institutions. The research methodology included demographic analysis, factor analysis, structural equation modeling and mediation analysis.

Findings - The participative decision-making affected moral, knowledge and attitude that contributed to leadership performance. Besides, the only attitude mediated the relationship between participative decisionmaking and leadership performance.
\end{abstract}

Research limitations/implications - The study is limited to private K12 schools in Iraq. Therefore, the findings cannot be generalized. It might guide educational institutes to change their management style.

Originality/value - The study delivers a unique insight into education in Iraq.

Keywords Performance, Leadership, Education, Decision-making, Ethics

Paper type Research paper

\section{Introduction}

The participative decision-making (PDM) has become popular in education due to the autocratic managerial style in educational institutes where the administrators who have power make the decisions, and those who work at the middle and lower levels implement instructions without any input (Hallinger, 1992). The educational institutes moved toward a more subordinate-centered management style by which students and educators could positively benefit from this democratic process (Lindelow, 1989). Likewise, a decentralized

(C) Nuri Gökhan Torlak, Ahmet Demir and Taylan Budur. Published in Rajagiri Management Journal. Published by Emerald Publishing Limited. This article is published under the Creative Commons Attribution (CC BY 4.0) licence. Anyone may reproduce, distribute, translate and create derivative works of this article (for both commercial and non-commercial purposes), subject to full attribution to the original publication and authors. The full terms of this licence maybe seen at http://creativecommons.org/licences/by/4.0/legalcode

Leadership and performance links

Received 17 October 2020 Revised 22 December 2020 Accepted 6 January 2021 
RAMJ

16,1

management style would challenge the bureaucratic structure of educational institutes and allow educators to involve in planning activities, which maintain increased educator commitment and morale and improve innovation, high job satisfaction and a healthy corporate culture (Somech, 2002). Smylie et al. (1996) found that a correct implementation of PDM will lead to gatherings and more successful educational institutes. However, PDM should be context-dependent but not universal. After all, those who engage in the PDM process should possess the traits of relevance, expertise and commitment (Hoy and Tarter, 1993). So, PDM will increase industrial democracy, productivity and effectiveness in the decision-making process via shared responsibility, diverse ideas, knowledge and experiences in organizations (Lunenburg, 2011; Bree, 2017).

According to Keith (1996) and Somech (2002), PDM is grounded on democratic and human growth and development disputes. The democratic argument for PDM emphasizes that facilitating PDM is a moral necessity because individuals have the right to monitor their work and their lives. However, the human growth and development argument for PDM supports the increase of individual involvement, autonomy and responsibility, which safeguards growth and learning within the workplace (Keith, 1996). This study incorporates these two arguments.

Likewise, ethical leadership (EL) in education emphasized the importance of moral reasoning based on justice and the ethic of care (Noddings, 1984). Shapiro and Stefkovich (2016) identified the traits of EL in education that entail the leader's conduct, decisionmaking and interaction with people. They also emphasized the multiple ethical paradigms by which school leaders analyze and use different moral views in their work. Some of them include the ethic of critique (i.e. confronting norms and power structures that discriminate against weaker societies) and the ethic of the profession (i.e. maintaining professional standards to meet the best interest). This study considers these viewpoints.

One of the authors of this paper witnessed some difficulties encountered by teachers and administrators working in private K12 schools in Iraq. Several teachers were assigned a significant volume of administrative work, while others continuously performed only teaching. Likewise, some teachers bent the rules for employees who leave the school for personal work and neglect their teaching duties. Furthermore, meetings were arranged and often ended up with unilateral decisions and specific commitments, including clear deadlines to improve and sustain the quality of education. Nonetheless, due to the emergence of unexpected events and the absence of proper follow-ups on promises, some administrators failed to fulfill commitments as agreed. The most undesirable actions were neither involving teachers in decision-making and nor informing all the participants of the meeting about the change that prevented mutually beneficial consequences in decisionmaking and generated a distressing work environment. Likewise, some influential managers lacked a vision, inspiration, risk-taking, knowledge, intellectual capacity, interpersonal skill and appreciation stuck with mental models, resulting in weak, uncommitted, and displeased teachers and administrative staff who viewed the leaders of the K12 school as unfair, unproductive, self-interested and relentless. Hence, the subordinates did not work joyfully toward achieving schools' objectives, which adversely affected the effectiveness of their superiors. Due to autocratic administration at K12 schools, goal incongruity, mistrust, discouragement and unresponsiveness became predominant issues. Besides, the K12 schools had seven branches in Sulaimania and several branches in Erbil, Kirkuk, Baghdad and Basra. The K12 schools centralized curriculum development, teacher training, R\&D, advertisement and consultation, though each branch had its general manager with a vice-general manager for extracurricular activities, a vice-general manager for primary degrees, and a vice-general manager for middle and higher degrees. The 
followers in the K12 schools obeyed the top management to achieve short-term objectives (Rarick et al., 2014; Hassan, 2015).

Yates (2014) considered PDM as a vital characteristic of ethical leaders that fosters employee commitment. Canaya (2008) found that PDM significantly positively affects the ethicality of teachers in public schools. Smylie et al. (1996) and Sukirno and Siengthai (2011) also detected PDM significantly influences the knowledge $(\mathrm{K})$ of teachers. Furthermore, while Locke and Schweiger (1979) and Latham and Steele (1983) noted the effect of PDM on attitude (A), Cansoy (2019) found a positive relationship between the encouragement of and performance links principals for participation and job satisfaction of teachers at schools in Turkey.

Besides, Cuellar and Giles (2012) detected a positive relationship between EL and helping and problem-solving behaviors at schools. Likewise, Eyal et al. (2011) found that critique, care, and profession are the most widely adopted ethical paradigms by aspiring principals to solve ethical challenges in training programs. Drago-Severson et al. (2018) also reported that principals often use their developmental capacities in solving problems in schools. Ultimately, Begley (2006) found that school principals used ethical issues to support their actions and strategies.

Moreover, Conway (1984) and Bouwmans et al. (2017) found a significant relationship between PDM and performance in educational institutes. Sukirno and Siengthai (2011) also showed that the involvement of lecturers in the operational and administrative activities of higher educational institutes increased the performance of both the lecturer and the university.

As a final point, Cray et al. (2007) and Eberlin and Tatum (2008) detected a significant relationship between decision-making and leadership styles that make decision-making a critical role of a leader. To be specific, Ylldirım et al. (2019) found a significant association between PDM and EL, and Woodruff et al. (2014) detected a positive relationship between EL and performance. Also, the performance of the leader (LP) affects organizational success (Covey, 1989). Hence, leadership values could mediate the relationship between the leader's decision-making and performance.

This paper aims to investigate the relationships between PDM and EL that contribute to the LP and the mediating effect of EL on the PDM and LP association, which might make the leaders leave the compliance behavior and enhance their performance at private K12 schools in Iraq.

The paper first describes PDM, EL and LP, and then reveals the studies on the relationships between PDM, EL and LP, and develops hypotheses. It explains the proposed model, sample and instrumentation. Then, it provides analyses of demographics, measurement model and mediation with the empirical findings. Next, it compares the results of this study with the research works based on the relevant literature and presents recommendations to the educational institutes. It briefly evaluates findings from theoretical and managerial perspectives with the shortcomings of this study and further research agenda. The conclusion summarizes the chief accomplishments of this study.

\section{Theoretical background}

\subsection{Participative decision-making}

$\mathrm{PDM}$ is employee involvement in decision-making that promotes idea generation, employee commitment, productivity and institutional welfare. Goleman (2000), Probst (2005), Bhatti and Nawab (2011) and Sofijanova and Chatleska (2013). The ideas, expertise and efforts of employees contributing to the decision-making process ease to overcome issues and achieve organizational goals (Busck et al., 2010; Silla et al., 2020). As noted by Noah (2008), employees influence planning, leading and controlling through PDM. Likewise, employees 
RAMJ

16,1

experience a sense of belongingness to their workplace and close the gaps between management and employees through PDM (Helms, 2006). As well, Vangrieken et al. (2016) and Bouwmans et al. (2017) detected PDM improves team-learning among the teachers by matching knowledge sharing with innovative ideas, which increases school effectiveness. Ultimately, as identified by Sagie and Aycan (2003), PDM has four categories: including the direct interaction of employees with their superiors; representative involvement in decisionmaking; paternalistic PDM between the superior and subordinate; and pseudo-PDM in which superiors pretend they do not know the best for their subordinates.

There are several effective processes in PDM that assist organizations in encountering complex issues. While brainstorming eases the expression of many valuable ideas, the nominal group technique secures equal participation of participants in decision-making (Redman, 1992: Roth et al., 1995; Boddy, 2012). However, the Delphi technique connects people who are geographically dispersed (Rowe and Wright, 1999; Abdolhosseinzadeh and Abdolhamid, 2020).

In PDM, the participants might prefer the group cohesiveness to the realistic evaluation of alternatives within problem-solving - groupthink (McMrry, 2003). Likewise, the participants could desire to accept more risks in PDM due to the sharing of the responsibilities for the consequences of a decision - risky shift, which might cause harmful situations for the organization (Stoner, 1968; Valverde-Moreno et al., 2020). Ultimately, an individual within the group might develop the attitude in the rational and socially desirable direction through group discussion due to the desire to be perceived favorably by others, which could lead to a maximum point - group polarization (Isenberg, 1986; Curseu et al., 2016).

\subsection{Ethical leadership}

According to Boyatzis (1982), Blanchard and Peale (1988) and Kanungo and Conger (1993), EL promotes "genuine altruism," "affiliative interest," "empowerment," and "patience" leading to personal sacrifice, interpersonal competence, followers' self-growth, and the leader's calmness in difficulties respectively. As revealed by Brown et al. (2005), EL is "the demonstration of normatively appropriate conduct through personal actions and interpersonal relationships, and the promotion of such conduct to followers through twoway communication, reinforcement and decision-making." Hence, the followers envisage leader effectiveness, leader's extra effort on the job, and employee commitment. As noted by Trevino et al. (2000, 2003), EL possesses two elements: "moral person" and "moral manager." The former implies followers' perceptions of the leader's characteristics, personality and humane motivation. To be specific, the leader should be honest, trustworthy and fair. Moreover, the leader cares about people and society as they decide and behave ethically in their personal and professional lives. The latter represents that the leader explicitly and intentionally communicates moral norms and values and uses the reward and punishment system to hold followers responsible for ethical conduct. Consequently, the leader draws followers' attention by being a prominent figure. Hence, the EL should possess wisdom, moral competence, honesty, caring, fairness, humility and tolerance for mistakes (Trevino et al., 2000). Accordingly, EL exhibits three characteristics: moral (M), knowledge (K) and attitude (A).

As noted by Palanski and Yammarino (2007), M represents justice, honesty and courage. While justice refers to objectivity, equality and fairness to others, honesty implies trustworthiness and truthfulness. Moreover, courage embodies the stability of the mind in a problematic situation. Riggio et al. (2010), Hackett and Wang (2012), Morales-Sánchez and 
Cabello-Medina (2013) and Zaim et al. (2020) also considered moral features as the knowledge that simplifies ethical behaviors.

The leader proposes a collective vision at the workplace that refers to tacit $\mathrm{K}$, encouraging organizational members to assume vaster responsibility, innovation, ethical judgment and problem-solving skills (Melé, 2005; García-Morales et al., 2008; MoralesSánchez and Cabello-Medina (2013). Moreover, Wong et al. (2018) noted that sharing K among the members significantly affects their creativity. In this respect, $\mathrm{K}$ refers to the ability of judgment between variables in ethical decision-making (Morales-Sánchez and Cabello-Medina, 2013; Budur, 2018). Additionally, $\mathrm{K}$ is the collection of wisdom, which develops a moral judgment (Melé, 2005). Accordingly, knowledge and attitude sustain a significant impact on EL (Ferrell and Gresham, 1985).

A includes support and appreciation of others (Ajzen and Fishbein, 2005; Exline and Hill, 2012) refers to the leader's courtesy and humbleness. While the former comprises the leader's control over their anger, kindness and tolerance to failure, the latter signifies modesty and respect for others (Tangney, 2000).

\subsection{Leadership performance}

As noted by Alexandra (2013), performance refers to the capability of achieving preset goals using employees efficiently and effectively. Richard et al. (2009) revealed that performing includes the actual performance of an employee as gauged against the desired goals. However, Robbins and Coulter (2013) emphasized that only the committed employees embracing the organization's vision and mission direct their actions toward goal achievement. Hence, employees should possess a sense of duty in the execution of the task (Manning and Curtis, 2009). Moreover, as revealed by Griffin and Lopez (2005), employees' attitudes toward their job will affect leadership performance. Therefore, leaders should search for ways to improve employee satisfaction, which results in organizational effectiveness (Covey, 1989; Jacobs and Singell, 1993; Robbins and Coulter, 2013). Though the leaders often use financial indicators in the achievement of organizational goals, they should also consider physical and mental effort applied to a task (Venkatraman and Ramanujam, 1986; Armstrong, 2006). So, the survival of an organization is dependent upon both financial competitiveness and fair treatment of subordinates' values, beliefs and interests (Paauwe, 2004). McCann (2011) noted committed and satisfied lecturers, teachers, and educators greatly influence the performance of students as well as the long-term effectiveness of their educational institutions.

\section{Literature review and hypotheses}

3.1 Relationships between participative decision-making and ethical leadership

Locke and Schweiger (1979) and Steel and Mento (1987) found a significant positive relationship between PDM and M. Lenssen et al. (2009) detected that PDM leverages the fairness perception of employees about their organization, which demonstrate the moral sense in the workplace. Likewise, Sukirno and Siengthai (2011) noted that PDM influences the teacher's insight and knowledge. Arar et al. (2016) also found a significant positive relationship between EL and decision-making in the Arab educational system in Israel.

Besides, Ho (2010) found that teacher's participation in curriculum and pedagogical decisions positively affect their professional knowledge and capability. Bouwmans et al. (2017) noted a significant positive relationship between PDM and the teacher's innovation and knowledge sharing, resulting in high performance. Similarly, Yildırım et al. (2019) found a positive relationship between PDM and $\mathrm{K}$ in schools. 
RAMJ

16,1

Moreover, Sagie et al. (1995) noted that PDM affects attitudinal outcomes. As revealed by Subbulakshmi et al. (2014), PDM in quality circles in manufacturing firms affects the employee attitude. Shaed et al. (2015) also detected a significant positive relationship between PDM and employee attitudes. Ultimately, Pathak and Rana (2019) found an association between job-related attitudes and employee participation at workplaces. Therefore, the researchers formulated the following hypotheses:

H1. PDM has a significant direct effect on $\mathrm{M}$.

H2. PDM has a significant direct effect on $\mathrm{K}$.

H3. PDM has a significant direct effect on $\mathrm{A}$.

\subsection{Relationships between ethical leadership and leadership performance}

Melé (2005) found that the moral development and behavior of the accountants significantly affect their performance. Reave (2005) detected that integrity, honesty and humility affect the LP. García-Morales et al. (2008) also revealed that EL positively affects the motivation of the employee for the effectiveness of the organization. Likewise, Johnson et al. (2011) found that humility and honesty positively influence employee performance. Morales-Sánchez and Cabello-Medina (2013) also revealed that moral virtues enable the leaders to understand and solve problems wisely, leading to high organizational performance. Furthermore, courage, temperance, justice, prudence, humanity and truthfulness positively affect the LP (Riggio et al., 2010; Hackett and Wang, 2012). Khuong and Hoang (2015), Palanski et al. (2015), Faris and Abdalla (2018) and Sosik et al. (2019) also noted that the leader's courage, fairness and humility significantly and positively influence employee performance.

Likewise, the leader's $\mathrm{K}$ significantly correlates with leader achievement and performance (Connelly et al., 2000; Mumford et al., 2000). Besides, while Sosik et al. (2012) found integrity, bravery, perspective and social intelligence influence executive performance, Zacher et al. (2014) noted personal wisdom positively affects the leaderfollower relationship and increases the subordinate's well-being at the workplace.

Also, religiosity and spirituality significantly affect job performance (Osman-Gani et al., 2013). Ultimately, humility provides physical and mental health and improves performance (Woodruff et al., 2014). Therefore, the researchers formulated the following hypotheses:

H4. M has a significant direct effect on LP.

H5. K has a significant direct effect on LP.

H6. A has a significant direct effect on LP.

\subsection{Mediating effect of ethical leadership on the relationship between participative decision- making and leadership performance}

One of the authors of this study witnessed several moral difficulties encountered by the teachers and administrators working in private K12 schools in Iraq. The managers frequently made decisions and announced them to the members of the schools. They arranged so-called productive meetings with the staff, though they did not allow them to talk openly with the management about the problems and goals of the schools. Likewise, the managers did not seek information and opinions of school members, leading consensus and decisions. Hence, teachers did not possess a sense of effort in performing tasks and were 
mostly dissatisfied with their work. The problem at K12 schools represented an autocratic leader behavior that did not empower teachers and the administrative staff to offer suggestions concerning the organizational goals and strategies. In this case, the authors assumed, if the leaders of K12 schools sought the preferences of followers or involved them in decision-making, they could be impartial, creative and benevolent in the eyes of subordinates, resulting in promoted leader effectiveness. Wainaina et al. (2014), Arar et al. (2016) and Yildırım et al. (2019) found PDM significantly influenced EL and staff commitment in educational institutions. As well, Mumford et al. (2000), and performance links Sosik et al. (2012) and Woodruff et al. (2014) detected a positive relationship between EL and performance. However, Sagie (1994) noted that A mediates the relationship between PDM and performance in a non-educational milieu. Besides, Wagner (1994) and Black and Gregersen (1997) detected PDM positively and significantly affects employee performance by generating alternatives in planning. Likewise, Conway (1984) found PDM enhances the acceptance of a decision and secures quality and performance in teaching. Ultimately, Locke and Schweiger (1979), Ndiku et al. (2009) and Sukirno and Siengthai (2011) found PDM promotes the teacher's moral, new knowledge and the interaction between teachers and managers, resulting in high performance at schools. Based on the research site observations and the literature, the researchers formulated the following hypotheses:

H4a. M has a mediating effect between PDM and LP.

H5a. K has a mediating effect between PDM and LP.

H6a. A has a mediating effect between PDM and LP.

\section{Research methodology}

\subsection{The proposed model}

To test the hypothesized relationships of the proposed model, structural equation modeling (SEM) is used. The proposed model is illustrated in Figure 1.

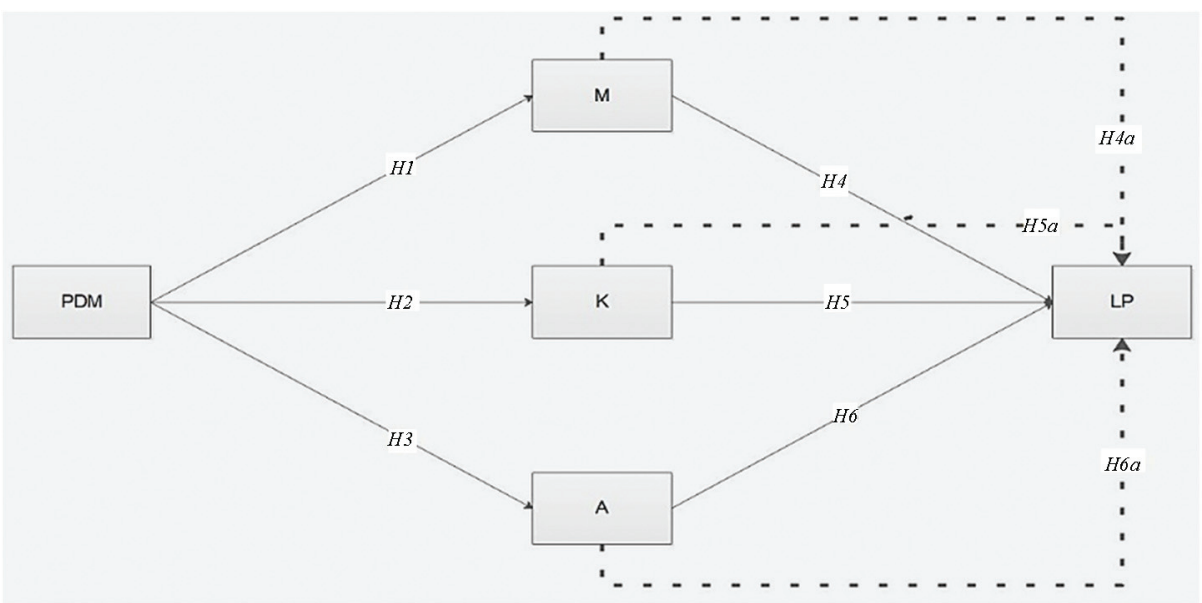

Note: Solid lines illustrate direct relationships and thick dashed lines illustrate the mediator effects

Figure 1. Model of the study 
RAMJ

16,1

4.2 Sample

One of the authors of this study was the consultant of the K12 schools' group in the Kurdistan Region of Iraq. The group had ten private schools in the region and invited one of the authors of this paper to elaborate on the chief managerial problems in schools. Hence, the authors collected data from K12 schools for counseling purposes.

The researchers collected the sample data by using a stratified random sampling method from 207 teachers who work full-time at private K12 schools in the Kurdistan Region of Iraq. Therefore, the researchers selected each school as a separate stratum. The administrative board of the schools recognized the research appropriately and administered the process, which helped ensure quality and sensitivity in the feedback. At each school, there were between 30 and 50 teaching staff.

In total, there were approximately 500 teachers in the private K12 schools the authors sampled. Initially, the researchers distributed questionnaires by hand in the Kurdish, English and Turkish languages and briefly explained questions to the participants. At that time, the researchers collected responses by examining each participant at the school. However, only 279 participants responded to the questionnaire, with 72 being returned incomplete and, therefore, eliminated from further analysis. Considering the valid responses, the number of fulfilling the questionnaire was a minimum of 16 and a maximum of 33 per school. As follows, the response rate comprised $40 \%$.

The study proposed Harman's single factor test to prevent the usual method variance problem that indicated that there was no common variance problem because the explained variance of the first dimension was $39 \%$, which was far below the threshold of $50 \%$.

\subsection{Instrumentation}

In the survey, there were three dimensions concerning EL: M, K and A scales in 29 items. The researchers borrowed M from the work of Ngambi (2011) and Riggio et al. (2010); K from the work of Berson et al. (2001) and Anwar et al. (2013), and A from the work of Owens (2009) and Bright et al. (2006). The authors also borrowed PDM from the work of Smylie et al. (1996) and LP from the work of Owens and Hekman (2016) and Tarim et al. (2014). The researchers modified all items to be appropriate for the current study (Table A1).

Based on the initial reliability and exploratory factor analysis (EFA) results, the authors dropped four items from the questionnaire. After all, M included ten items with a Cronbach's alpha value of 0.925 , $\mathrm{K}$ nine items with a Cronbach's alpha value of 0.953 , and A six items with a Cronbach's alpha value of 0.902 . PDM comprised three items with a Cronbach's alpha value of 0.880 and LP four items with a Cronbach's alpha value of 0.790 (Table 1). The researchers used a seven-point Likert-type scale. Answers to questions ranged from 1 (strongly disagree) to 7 (strongly agree).

\section{Data analysis and research findings}

The analysis methodology includes IBM SPSS for EFA and IBM AMOS 23 software for SEM.

\subsection{Demographic analysis}

The demographic information included gender, job experience, position and the subject of teaching. The percentage of males and females are perfectly distributed as 50 . The majority of the target population is teachers with $79 \%$, while psychological counselors are $12.9 \%$; senior teachers are $7.3 \%$ and deputy directors are only $0.6 \% .60 .6 \%$ of participants have job experience between $1-6$ years; $31.1 \%$ have job experience between 7 and 15 years, and only 


\begin{tabular}{|c|c|c|c|c|c|c|c|c|c|}
\hline Q & M & S.D. & $\mathrm{C}$ & A & K & M & LP & PDM & 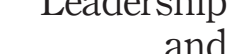 \\
\hline M1 & 5.50 & 1.622 & 0.751 & & & 0.75 & & & performance \\
\hline M2 & 5.39 & 1.689 & 0.628 & & & 0.71 & & & \\
\hline M4 & 5.19 & 1.732 & 0.524 & & & 0.48 & & & \\
\hline M5 & 5.45 & 1.714 & 0.797 & & & 0.84 & & & \\
\hline M6 & 4.88 & 1.911 & 0.655 & & & 0.79 & & & \\
\hline M7 & 5.59 & 1.568 & 0.766 & & & 0.55 & & & 71 \\
\hline M8 & 5.36 & 1.784 & 0.782 & & & 0.79 & & & \\
\hline M9 & 6.02 & 1.528 & 0.589 & & & 0.50 & & & \\
\hline M10 & 5.81 & 1.504 & 0.737 & & & 0.62 & & & \\
\hline M11 & 5.79 & 1.504 & 0.721 & & & 0.58 & & & \\
\hline K1 & 5.31 & 1.801 & 0.721 & & 0.54 & & & & \\
\hline K2 & 5.47 & 1.616 & 0.616 & & 0.51 & & & & \\
\hline K3 & 5.36 & 1.619 & 0.785 & & 0.59 & & & & \\
\hline K4 & 5.22 & 1.63 & 0.792 & & 0.57 & & & & \\
\hline K5 & 5.30 & 1.837 & 0.657 & & 0.55 & & & & \\
\hline K6 & 5.09 & 1.629 & 0.766 & & 0.72 & & & & \\
\hline K7 & 5.22 & 1.662 & 0.759 & & 0.67 & & & & \\
\hline K8 & 5.35 & 1.563 & 0.783 & & 0.60 & & & & \\
\hline K9 & 5.39 & 1.569 & 0.586 & & 0.51 & & & & \\
\hline A1 & 5.45 & 1.633 & 0.568 & 0.72 & & & & & \\
\hline A2 & 5.42 & 1.752 & 0.713 & 0.79 & & & & & \\
\hline A3 & 5.59 & 1.619 & 0.796 & 0.82 & & & & & \\
\hline A4 & 5.80 & 1.487 & 0.778 & 0.79 & & & & & \\
\hline A5 & 5.65 & 1.703 & 0.572 & 0.60 & & & & & \\
\hline A8 & 5.45 & 1.728 & 0.562 & 0.61 & & & & & \\
\hline PDM1 & 5.01 & 1.902 & 0.691 & & & & & 0.72 & \\
\hline PDM2 & 5.39 & 1.717 & 0.811 & & & & & 0.75 & \\
\hline PDM3 & 5.32 & 1.566 & 0.749 & & & & & 0.73 & \\
\hline LP1 & 5.35 & 1.708 & 0.795 & & & & 0.50 & & \\
\hline LP2 & 4.96 & 1.943 & 0.554 & & & & 0.50 & & \\
\hline LP3 & 5.26 & 1.854 & 0.724 & & & & 0.55 & & \\
\hline LP4 & 5.03 & 1.757 & 0.623 & & & & 0.50 & & \\
\hline \multirow{6}{*}{\multicolumn{2}{|c|}{$\begin{array}{l}\text { Dimension } \\
\text { M } \\
\text { PDM } \\
\text { K } \\
\text { LP } \\
\text { A }\end{array}$}} & \multicolumn{2}{|c|}{ Eigen values } & Extr & 1 variance & & \multicolumn{2}{|c|}{ Cronbach's alpha } & \\
\hline & & \multicolumn{2}{|c|}{14.494} & & 105 & & \multicolumn{2}{|c|}{0.925} & \\
\hline & & \multicolumn{2}{|c|}{2.774} & & 113 & & \multicolumn{2}{|c|}{0.881} & \\
\hline & & \multicolumn{2}{|c|}{1.843} & & 106 & & \multicolumn{2}{|c|}{0.953} & \\
\hline & & \multicolumn{2}{|c|}{1.205} & & 524 & & \multicolumn{2}{|c|}{0.791} & \\
\hline & & \multicolumn{2}{|c|}{1.063} & & 382 & & \multicolumn{2}{|c|}{0.902} & \\
\hline \multicolumn{9}{|c|}{$\begin{array}{l}\text { Notes: Extraction method: Principal component analysis; a. Rotation converged in eight iterations; } \\
\text { Rotation method: Varimax with Kaiser normalization; Q:question; L:Load; M:Mean; S.D.: Standard } \\
\text { deviation; C:Communalities }\end{array}$} & $\begin{array}{r}\text { Table } 1 . \\
\text { EFA Results }\end{array}$ \\
\hline
\end{tabular}

$8.2 \%$ have job experience over 16 years. Finally, while $25.8 \%$ of participants teach positivist sciences, $20.5 \%$ teach languages and $53.8 \%$ teach other subjects.

\subsection{Measurement model assessment}

5.2.1 Exploratory factor analysis. The researchers assessed the internal validity of the survey questionnaire by Cronbach's alpha that ranged between 0.791 and 0.953 which equally satisfy the recommended threshold value of 0.70 , thus meeting the reliability of the constructs. 
RAMJ

16,1

The researchers determined sample adequacy by both the Kaiser-Meyer-Olkin sampling adequacy (KMO) index and Bartlett's test of sphericity. KMO (0.96) is significantly above the threshold value of 0.7 , while Bartlett's test of sphericity is significant at $p \leq 0.01$ that confirms the appropriateness of data for EFA procedures.

EFA reduces the number of constructs. This is then followed by the eigenvalue of each factor, which must be equal to or above one so that the concerning clusters of questions can be considered as a factor. Five dimensions have an eigenvalue of the above one. Those factors also explain $74 \%$ of the variance. Descriptive statistics results are provided in Table 1. The average of EL results varies between 4.879 and 6.02, while PDM and LP averages are between 4.96 and 5.35 .

Factor loadings of $\mathrm{M}$ range between 0.476 and 0.835 ; $\mathrm{K}$ between 0.505 and 0.716 ; and $\mathrm{A}$ between 0.598 and 0.817 , while PDM between 0.723 and 0.752 and LP between 0.495 and 0.502 , which are above the suggested value of 0.35 based on the sample size (Hair et al., 2010). Moreover, Cronbach's alphas for all dimensions are above 0.7, thus satisfying the reliability of the constructs (Table 1 ).

The researchers elaborated on the clusters of each dimension in which the questions under each construct are about justice, courage and honesty; knowledge and vision; and courtesy and humbleness.

Due to the concerning sequence of distribution, the first grouping could be considered as $\mathrm{M}$, the second grouping as $\mathrm{K}$ and the third grouping as $\mathrm{A}$. The results show that all items are appropriately classified under the concerning dimension by illustrating sufficient values that consider factor loadings, communalities and Cronbach's alphas (Table 1). These results prove that the constructs are conveniently formed.

5.2.2 Confirmatory factor analysis. The researchers used CFA to determine the dimensions that allowed EFA results to be analysed for further proof (Straub et al., 2004). Comparative and absolute model fit values are tracked. The comparative fit indexes such as CFI (0.95) and Trucker-Lewis' coefficient (TLI, 0.92) are above the threshold values (Olobatuyi, 2006). Furthermore, absolute fit indexes, chi-square $\left(X^{2}\right.$, 2.228), root mean square error of approximation (RMSEA, 0.067), good fit index (GFI, 0.87 ) and adjusted good fit index (AGFI, 0.82) are also at the acceptable levels (Marsh and Hocevar, 1988; Byrne, 2013).

As a part of validity tests, the researchers used discriminant validity (DV) and convergent validity $(\mathrm{CV})$ tests to understand whether the dimensions maintain the required distance from each other, while the items under each dimension have sufficient closeness to each other (Khine, 2013). DV is achieved because all square roots of average variance extracted are above the correlation coefficients of other dimensions.

$\mathrm{CV}$ is also assessed by the average variance extracted (AVE) holding a threshold value minimally 0.5 and composite reliability (C.R.) holding a minimal value 0.7 (Fornell and Larcker, 1981). CV is achieved due to the existence of composite reliability (C.R.) and average variance extracted (AVE) above the concerning thresholds for all dimensions (Table 2).

As a result, items, grouped under each factor, are adequate to construct a conceptual dimension. All CFA parameters and DV-CV validity prove this. So, the relevant model can be established with these valid and reliable dimensions.

\subsection{Measurement model analysis}

5.3.1 Structural equation modeling. The researchers developed SEM from three dimensions of EL and PDM to test hypotheses and evaluated LP as the outcome of the model. 


\begin{tabular}{|c|c|c|c|c|c|c|c|c|}
\hline & & & Estimate & Standardized estimate & S.E. & C.R. & $p$ & eadership \\
\hline K1 & $\leftarrow$ & \multirow[t]{9}{*}{$\mathrm{K}$} & Scaling & 0.838 & & & & erformance \\
\hline$K 2$ & $\leftarrow$ & & 0.845 & 0.790 & 0.061 & 13.84 & $* * *$ & \\
\hline K3 & $\leftarrow$ & & 0.97 & 0.904 & 0.056 & 17.394 & $* * * *$ & $\operatorname{lin} k s$ \\
\hline K4 & $\leftarrow$ & & 0.965 & 0.894 & 0.057 & 17.035 & $* * *$ & \\
\hline K5 & $\leftarrow$ & & 0.962 & 0.790 & 0.069 & 13.848 & $* * *$ & \\
\hline K6 & $\leftarrow$ & & 0.829 & 0.930 & 0.055 & 14.754 & $* * *$ & 73 \\
\hline$K 7$ & $\leftarrow$ & & 0.916 & 0.708 & 0.063 & 15.526 & $* * *$ & \\
\hline$K 8$ & $\leftarrow$ & & 0.879 & 0.783 & 0.053 & 14.752 & $* * *$ & \\
\hline K9 & $\leftarrow$ & & 0.838 & 0.854 & 0.064 & 15.426 & $* * *$ & \\
\hline$L P 1$ & $\leftarrow$ & \multirow[t]{4}{*}{ LP } & 0.866 & 0.930 & 0.07 & 12.382 & $* * *$ & \\
\hline LP2 & $\leftarrow$ & & Scaling & 0.708 & & & & \\
\hline$L P 3$ & $\leftarrow$ & & 0.759 & 0.802 & 0.071 & 11.153 & $* * *$ & \\
\hline LP4 & $\leftarrow$ & & 0.773 & 0.798 & 0.069 & 11.896 & $* * *$ & \\
\hline$M 1$ & $\leftarrow$ & \multirow[t]{10}{*}{ M } & 0.917 & 0.853 & 0.065 & 14.108 & $* * *$ & \\
\hline M2 & $\leftarrow$ & & 0.884 & 0.823 & 0.066 & 13.428 & $* * *$ & \\
\hline M4 & $\leftarrow$ & & 0.709 & 0.649 & 0.072 & 9.900 & **** & \\
\hline M5 & $\leftarrow$ & & Scaling & 0.795 & & & & \\
\hline M6 & $\leftarrow$ & & 0.948 & 0.846 & 0.059 & 16.102 & $* * *$ & \\
\hline$M 7$ & $\leftarrow$ & & 0.808 & 0.594 & 0.074 & 10.969 & $* * *$ & \\
\hline M8 & $\leftarrow$ & & 0.909 & 0.742 & 0.055 & 16.383 & $* * *$ & \\
\hline M9 & $\leftarrow$ & & 0.859 & 0.694 & 0.08 & 10.769 & $* * *$ & \\
\hline M10 & $\leftarrow$ & & 0.775 & 0.642 & 0.079 & 9.7830 & $* * *$ & \\
\hline M11 & $\leftarrow$ & & 0.877 & 0.757 & 0.073 & 12.010 & $* * *$ & \\
\hline$A 1$ & $\leftarrow$ & \multirow[t]{6}{*}{ A } & 0.812 & 0.749 & 0.061 & 13.315 & $* * *$ & \\
\hline A2 & $\leftarrow$ & & 0.951 & 0.882 & 0.048 & 19.924 & $* * * *$ & \\
\hline A3 & $\leftarrow$ & & Scaling & 0.872 & & & & \\
\hline A4 & $\leftarrow$ & & 0.938 & 0.834 & 0.059 & 15.998 & $* * *$ & \\
\hline A5 & $\leftarrow$ & & 0.8 & 0.782 & 0.061 & 13.077 & $* * *$ & \\
\hline A8 & $\leftarrow$ & & 0.869 & 0.787 & 0.066 & 13.253 & $* * *$ & \\
\hline PDM1 & $\leftarrow$ & \multirow[t]{3}{*}{ PDM } & 0.87 & 0.736 & 0.064 & 13.517 & $* * *$ & \\
\hline PDM2 & $\leftarrow$ & & Scaling & 0.936 & & & & \\
\hline \multirow[t]{2}{*}{ PDM3 } & $\leftarrow$ & & 0.874 & 0.897 & 0.044 & 19.935 & $* * *$ & \\
\hline & C.R. & AVE & M & $\mathrm{K}$ & LP & A & PDM & \\
\hline$M$ & 0.925 & 0.554 & $0.935^{\mathrm{a}}$ & & & & & \\
\hline$K$ & 0.925 & 0.713 & $0.925^{\mathrm{b}}$ & 0.945 & & & & \\
\hline$L P$ & 0.809 & 0.683 & 0.881 & 0.92 & 0.936 & & & \\
\hline$A$ & 0.931 & 0.573 & 0.889 & 0.932 & 0.922 & 0.947 & & \\
\hline$P D M$ & 0.895 & 0.741 & 0.788 & 0.762 & 0.756 & 0.769 & 0.861 & $\begin{array}{l}\text { CFA, Discriminant } \\
\text { and convergent }\end{array}$ \\
\hline \multicolumn{9}{|c|}{ Notes: ${ }^{\mathrm{a} S q u a r e}$ root of average variance extracted in italic, ${ }^{\mathrm{b}}$ Correlation coefficients not in italic } \\
\hline
\end{tabular}

SEM investigates the direct and indirect effects of independent variables on dependent variables. Table 3 illustrates the results of direct effects. PDM significantly positively affects $M(\beta=0.789$, $t=9.550, p<0.01), K(\beta=0.763, t=7.423, p<0.01)$ and $A(\beta=0.771, t=9.872, p<0.01)$ perceptions of employees. Therefore, the data supported $H 1, H 2$ and $H 3$ (Table 3) (Figure 2).

Furthermore, $M(\beta=0.215, t=1.963, p<0.05), K(\beta=0.281, t=1.973, p<0.05)$ and $A(\beta=0.461, t=2.196, p<0.05)$ significantly positively influence LP. Therefore, the data supported H4, H5 and H6 (Table 3) (Figure 2).

According to the results, PDM explains the overall variance (i.e. square of multiple correlations) of $62 \%$ in $\mathrm{M}$; $61 \%$ in $\mathrm{K}$; and $45 \%$ in $\mathrm{A}$. M, $\mathrm{K}$ and $\mathrm{A}$ also explain $88 \%$ of variance about LP. 
RAMJ

16,1

\subsection{Mediation analysis}

To test the mediation effects of M, K, and A between PDM and LP, the researchers used bootstrapping of IBM AMOS software. Furthermore, MacKinnon et al. (1995) suggested that the Aroian test performs best when the sample size is above 50. Due to the sample size that is well above the threshold, the authors used the Aroian test.

PDM positively significantly mediates $(\beta=0.817, P<0.01) \mathrm{LP}$. In elaborating mediators, Table 4 illustrates that A significantly mediates the relationships between PDM and LP. Besides, M and K did not mediate relationships between PDM and LP significantly. Therefore, EL partially mediates the relations between PDM and LP.

\begin{tabular}{llllcccl}
\hline Hypothesis & Dependent variable & & Independent variable & Estimate & S.E. & $p$ & H.R. \\
\hline$H 1$ & M & $\leftarrow$ & PDM & 0.789 & 0.08 & $p<0.01$ & Supported \\
$H 2$ & K & $\leftarrow$ & PDM & 0.763 & 0.09 & $p<0.01$ & Supported \\
$H 3$ & A & $\leftarrow$ & PDM & 0.771 & 0.08 & $p<0.01$ & Supported \\
$H 4$ & LP & $\leftarrow$ & M & 0.215 & 0.15 & $p<0.05$ & Supported \\
$H 5$ & LP & $\leftarrow$ & K & 0.284 & 0.28 & $p<0.05$ & Supported \\
H6 & LP & $\leftarrow$ & A & 0.461 & 0.23 & $p<0.05$ & Supported
\end{tabular}

Table 3.

Model results

Notes: S.E: Standard error; P:Significance level; H.R: Hypothesis result

Figure 2.

Results of hypothesized model

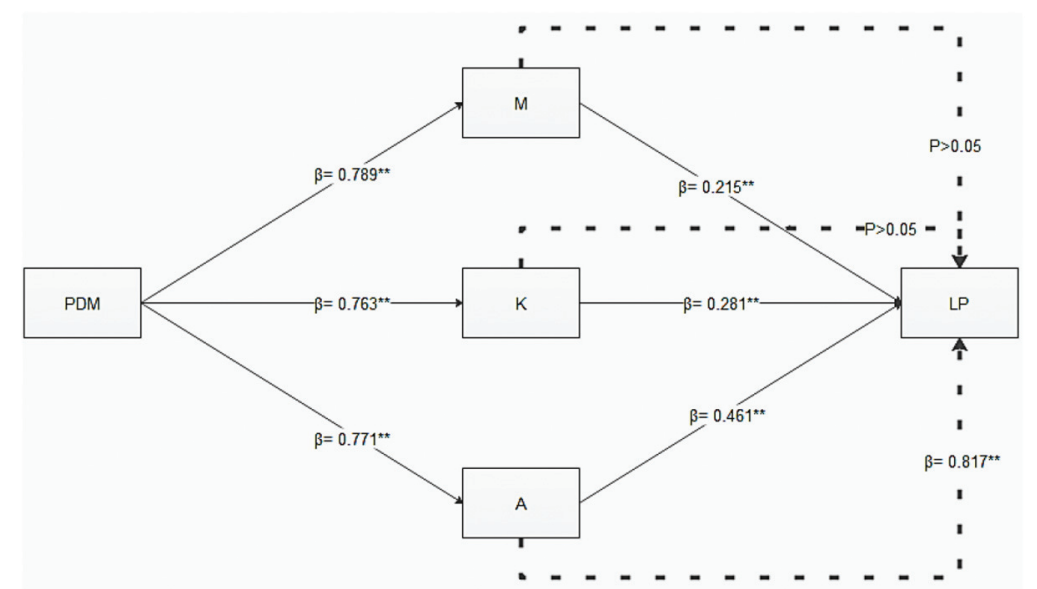

Note: $* *=$ Highly significant; $*=$ significant; Critical t-value: $1.96 p<0.05$ and $2.58 p<0.01$ two tailed; straight line: supported hypothesis; thick dashed lines: mediating effects; $p>0.05$ : not supported mediating effects
Table 4.

Mediating effect test results

\begin{tabular}{lccccl}
\hline Independent variable & Mediator & Dependent variable & Aroian test statistics & pvalue & Result \\
\hline PDM & M & LP & 1.93 & 0.054 & Not supported \\
PDM & K & LP & 1.94 & 0.055 & Not supported \\
PDM & A & LP & 2.13 & 0.033 & Supported \\
\hline
\end{tabular}


Although $\mathrm{M}$ and $\mathrm{K}$ are very close to significant mediation, the authors cannot suggest the significant mediating effect due to $p$ values of $\mathrm{M}(0.054)$ and $\mathrm{K}(0.053)$, which are slightly above the $p$-value threshold that is expected to be below 0.05 . Furthermore, only A significantly mediates the relationship between PDM and LP. Therefore, the data supported $H 6 a$, while rejected $H 4 a$ and $H 5 a$.

Leadership and performance links

\section{Discussion}

The results of direct significant positive relationships between PDM and EL in this paper were similar to the outcomes of studies of Locke and Schweiger (1979), Steel and Mento (1987), Sagie et al. (1995), Cray et al. (2007), Eberlin and Tatum (2008), Lenssen et al. (2009), Ho (2010), Sukirno and Siengthai (2011), Subbulakshmi et al. (2014), Shaed (2015), Arar et al. (2016), Bouwmans et al. (2017), Yildırım et al. (2019) and Pathak and Rana (2019). Therefore, if the K12 school management fully involves teachers and administrators in decisionmaking, empowers them to make contributions concerning the school well-being, and uses consensus to make the final choice, the school members' leadership perception about management could become more optimistic. In other words, the subordinates could perceive their managers as fair, trustworthy, steady, communicative, creative and tolerant.

Likewise, the results of direct significant positive relationships between EL and LP in this paper were similar to the outcomes of works of Connelly et al. (2000), Mumford et al. (2000), Melé (2005), Reave (2005), García-Morales et al. (2008), Riggio et al. (2010), Eyal et al. (2011), Johnson et al. (2011), Cuellar and Giles (2012), Hackett and Wang (2012), Sosik et al. (2012), Morales-Sánchez and Cabello-Medina (2013), Osman-Gani et al. (2013), Zacher et al. (2014), Woodruff et al. (2014), Palanski et al. (2015), Khuong and Hoang (2015), Faris and Abdalla (2018) and Sosik et al. (2019). Therefore, if the K12 school management cares about justice, honesty and courage and behaves kindly and tolerant toward their subordinates, teachers/administrators could become committed. In other words, the followers could develop a sense of duty in task performance, embrace the mission and vision of K12 schools and direct their actions toward goal achievement and institutional welfare. Besides, in this study, A affected LP more than $\mathrm{M}$ and $\mathrm{K}$. This meant the K12 school members cared more about their managers' kindness, helpfulness and modesty than their knowledge and trust. So, K12 school management might give more attention to their attitudes that are the most critical indicators of their good performance.

Moreover, a significant mediator role of A between PDM and LP found in this work was consistent with the study of Sagie (1994). However, prior studies, such as Conway (1984), Wagner (1994), Black and Gregersen (1997) and Sukirno and Siengthai (2011), considered the sole relationship between PDM and LP and ignored the mediating effects of $\mathrm{M}$ and $\mathrm{K}$ on the PDM and LP relationship. As well, while Wainaina et al. (2014), Arar et al. (2016), and Y1ldirım et al. (2019) detected a significant relationship between PDM and EL, Mumford et al. (2000), Sosik et al. (2012) and Woodruff et al. (2014) found a positive association between EL and performance. Therefore, the K12 school management should be sympathetic and tolerant toward the opinions and suggestions of teachers and administrators in group debates and deliberations. To be specific, the K12 school management could recognize pluralism in selecting participants of the discussion, defining objectives of the school, exploring the issues, identifying options, researching options, comparing options, deciding action and monitoring/evaluating performance. The supportive behavior of K12 school management in deliberations and debates will close the gap between superior and subordinate and assist teachers and administrators in the achievement of the objectives of the school. 
RAMJ

16,1

\section{Theoretical implications}

The authors found PDM allowed the managers of the K12 schools to make decisions after considering the ideas of the teachers and the administrative staff, who could view the managers as fair, creative and helpful. In this way, the subordinates might consider their superiors as successful leaders. However, the kindness and humbleness of the managers were the chief causes of a high LP. Ultimately, the knowledge of the managers was an additional reason, which also affected the LP positively and more significantly than the M.

Many empirical studies in the education sector investigated the PDM (Hoy and Tarter, 1993; Canaya, 2008; Lenssen et al., 2009; Ndiku et al., 2009; Ho, 2010; Sukirno and Siengthai, 2011; Wainaina et al., 2014; Bouwmans et al., 2017; Y1ldrim et al., 2019), the EL (Lindelow, 1989; Melé, 2005; Lenssen et al., 2009; Eyal et al., 2011; Cuellar and Giles, 2012; Arar et al., 2016; Shapiro and Stefkovich, 2016; Cansoy, 2019) and the LP (Jacobs and Singell, 1993). However, there was no research considering the relationship between PDM, EL and LP. This study shows that the coercive work environment in the K12 schools shaped the distress and dissatisfaction of the teachers and administrative staff, limiting their good intentions for their jobs and extending the gap between the leader and the follower, resulting in the poor performance of the leader. However, the management might have adopted democratic and moral conduct, which could lead to leader effectiveness.

The leader's A had a considerable mediating effect on the relationship between PDM and LP. There was no study regarding this relationship reported in the literature. However, this paper indicates that $\mathrm{A}$ is indeed such a mediator.

\section{Managerial implications}

An emphasis on PDM might bring educators and administrators from different units and levels into active participation and encourages a careful and thorough debate for a variety of challenges and problems. However, the management of the K12 schools should ensure direct involvement and the modes of representation that allow participants the freedom to express themselves, which eases responsiveness to the dynamics of the situation. In doing so, a sense of involvement of employees in their workplace, their commitment to the school, as well as their work satisfaction, individual growth and mutual trust could increase. Likewise, the perception of supportive management among the personnel might assist in closing the gap between the administration and subordinates, resulting in moral, communicative and tolerant leader conduct. As well, the recognition of accomplishments and innovative ideas might ease the adaptation of an educational institute to the rapidly changing conditions of the learning environment. Hence, the managers should give the utmost care to the ideas of subordinates before they decide on an issue. Managers need to accommodate employees and empower them to make contributions regarding the well-being of the institution. In other words, the managers should involve followers in decision-making, seek their suggestions and reach consensus to make the final choice.

Besides, the study builds a bridge between PDM and EL that boosts LP. In particular, the management should be sensitive to followers' interests and consider them partners in problem-solving, which will cause the leader's sacrifice and the followers' self-growth. The leaders should foster teamwork, interdepartmental cooperation and programs in which the leaders and the representatives of teachers and administrative staff should compare and contrast alternative courses of action. Then, they should select the option that best protects the rights of all group members and secure the equal distribution of benefits and detriments of a decision based on social achievement. However, the leaders should evaluate problems in light of moral standards, remain calm in uncertainty and involve in personal risk to achieve the vision of K12 schools. 
"Moral altruism" and interpersonal competence of the leaders might guarantee their goal of accomplishment and organizational effectiveness. In doing so, the leader might abandon compliance behavior and personal empowerment and start with interacting with people and being loyal to ethical standards to meet the best interest. However, the absence of EL might promote a considerable distance between the leader and the organization members, a lack of trust in the leader and a poor leader performance.

\section{Limitations and future research}

This study is limited to only K12 schools in Iraq and cannot be generalized unless the other researchers further studied diverse organizations, cultures or countries. Moreover, the study focused on private K12 schools, which ignored the management in public schools. Also, the sample size could have been larger to sketch a more reliable picture for the literature. In the end, the authors analyzed the impact of PDM on the LP and ignored the issues of rewards and job design. However, future studies might examine the effect of the virtues of EL on organizational performance, employee commitment, job satisfaction, contextual and task performances and future optimism of employees.

\section{Conclusion}

This study investigated the relationships between PDM, EL and LP at K12 schools in Iraq and suggested that the school leaders could democratize their motives, their influence and their character in decision-making and interaction with followers that result in improved LP.

The leaders at K12 schools could encourage the participation of all units, levels and layers in a debate through evaluating various suggestions in the decision-making. In doing so, the leaders might secure fair treatment, judgment, honesty, creativity, shared vision, lenience, modesty and graciousness easing conciliation and consensus among the members of a discussion. In this way, the leaders will respect the right of organizational members to monitor their work and facilitate their involvement and autonomy.

Besides, the leaders could arrange periodic meetings, seminars and workshops in which equal treatment, risk-taking, honest behavior, faithfulness, sharing of technical knowledge, collective understandings, patience, thoughtfulness and humility should be prominent. The approach of the leaders might strengthen the group members' belief in the leader's skills, ensure the individuals' inspiration and willingness to work with the leader and assist the leader in accomplishing goals. Therefore, the leader will quit norms and power structures that discriminate against those who are silenced and alienated and be loyal to standards that meet the best interest.

Finally, the leaders could emphasize solely mercy, respect, care and humility that might facilitate the relationship between the incorporation of viewpoints of subordinates in decision-making and the leader's goal accomplishment as well as the subordinates' willingness to contribute to the welfare of the K12 schools.

\section{References}

Abdolhosseinzadeh, M. and Abdolhamid, M. (2020), "Presentation of a school of government model through a comparative study of selected schools", Kybernetes, Vol. 49 No. 12, doi: 10.1108/k-052019-0328.

Ajzen, I. and Fishbein, M. (2005), “The influence of attitudes on behavior”, in Albarracín D., Johnson B.T., Zanna M.P. (Eds), Handbook of Attitudes and Attitude Change, Erlbaum, Hillsdale, NJ, pp. 173-221. 
RAMJ

16,1

\section{8}

Alexandra, L.G. (2013), "Organizational learning and performance: conceptual model”, Proceedings of the 7th International Management Conference on New Management for the New Economy, November 7th- 8th, 2013, Bucharest.

Anwar, J., Hasnu, S. and Janjua, S.Y. (2013), "Knowledge, wisdom, leadership and vision: a conceptual framework for learning organizations", World Applied Sciences Journal, Vol. 28 No. 1, pp. 56-65.

Arar, K., Haj, I., Abramovitz, R. and Oplatka, I. (2016), "Ethical leadership in education and its relation to ethical decision-making: the case of Arab school leaders in Israel", Journal of Educational Administration, Vol. 54 No. 6, pp. 647-660.

Armstrong, M. (2006), "Competition in two-sided markets", The RAND Journal of Economics, Vol. 37 No. 3, pp. 668-691.

Begley, P.T. (2006), "Self-knowledge, capacity and sensitivity: prerequisites to authentic leadership by school principals", Journal of Educational Administration, Vol. 44 No. 6, pp. 570-589.

Berson, Y., Shamir, B., Avolio, B.J. and Popper, M. (2001), "The relationship between vision strength, leadership style, and context”, The Leadership Quarterly, Vol. 12 No. 1, pp. 53-73.

Bhatti, K. and Nawab, S. (2011), "Effect of direct participation on organizational commitment", International Journal of Business and Social Science, Vol. 2 No. 9.

Black, J.S. and Gregersen, H.B. (1997), "Participative decision-making: an integration of multiple dimensions", Human Relations, Vol. 50 No. 7, pp. 859-878.

Blanchard, K. and Peale, N.V. (1988), The Power of Ethical Management, Fawcett Crest, New York, NY.

Boddy, C. (2012), "The nominal group technique: an aid to brainstorming ideas in research", Qualitative Market Research: An International Journal, Vol. 15 No. 1, pp. 6-18.

Bouwmans, M., Runhaar, P., Wesselink, R. and Mulder, M. (2017), "Fostering teachers' team learning: an interplay between transformational leadership and participative decision-making?", Teaching and Teacher Education, Vol. 65, pp. 71-80.

Boyatzis, R.E. (1982), The Competent Manager: A Model for Effective Performance, Wiley, New York, NY.

Bree, R. (2017), "Perceptions of the value of participative decision making from a Nebraska school district", College of Education EdD Project Papers, Vol. 15, available at: https://repository.uwyo. edu/edd/15

Bright, D.S., Cameron, K.S. and Caza, A. (2006), "The amplifying and buffering effects of virtuousness in downsized organizations", Journal of Business Ethics, Vol. 64 No. 3, pp. 249-269.

Brown, M.E., Treviño, L.K. and Harrison, D.A. (2005), "Ethical leadership: a social learning perspective for construct development and testing", Organizational Behavior and Human Decision Processes, Vol. 97 No. 2, pp. 117-134.

Budur, T. (2018), "The impact of Al-Ghazali's virtues on organizational commitment and performance: a case study at private education institutions in Kurdistan region of Iraq", Icabep, Erbil-Iraq, Vol. 2, p. 21.

Busck, O., Knudsen, H. and Lind, J. (2010), "The transformation of employee participation: consequences for the work environment", Economic and Industrial Democracy, Vol. 31 No. 3, pp. 285-305.

Byrne, B.M. (2013), Structural Equation Modeling with LISREL, PRELIS, and SIMPLIS: Basic Concepts, Applications, and Programming, Psychology Press, New York, NY.

Canaya, S.P. (2008), "Participatory decision-making vis-a-vis teachers morale and students' achievement in public secondary schools in zamboanga city", Unpublished $\mathrm{PhD}$. Dissertation.

Cansoy, R. (2019), "The relationship between school principals' leadership behaviours and teachers' job satisfaction: a systematic review", International Education Studies, Vol. 12 No. 1, pp. 37-52. 
Connelly, M.S., Gilbert, J.A., Zaccaro, S.J., Threlfall, K.V., Marks, M.A. and Mumford, M.D. (2000), "Exploring the relationship of leadership skills and knowledge to leader performance", The Leadership Quarterly, Vol. 11 No. 1, pp. 65-86.

Conway, J.A. (1984), "The myth, mystery, and mastery of participative decision making in education", Educational Administration Quarterly, Vol. 20 No. 3, pp. 11-40.

Leadership and performance links

Covey, S. (1989), The 7 Habits of Highly Effective People, Free Press, New York, NY.

Cray, D., Inglis, L. and Freeman, S. (2007), "Managing the arts: leadership and decision-making under dual rationalities", The Journal of Arts Management, Law, and Society, Vol. 36 No. 4, pp. 295-313.

Cuellar, C. and Giles, D.L. (2012), "Ethical practice: a study of Chilean school leaders", Journal of Educational Administration, Vol. 50 No. 4, pp. 420-436.

Curseu, P.L., Schruijer, S.G. and Fodor, O.C. (2016), "Decision rules, escalation of commitment and sensitivity to framing in group decision-making", Management Decision, Vol. 54 No. 7, pp. 1649-1668.

Drago-Severson, E., Maslin-Ostrowski, P. and Blum-Destefano, J. (2018), "Looking behind the curtain: principals' internal experiences of managing pressing challenges", Journal of School Leadership, Vol. 28 No. 3, pp. 315-343.

Eberlin, R.J. and Tatum, B.C. (2008), "Making just decisions: organizational justice, decision-making, and leadership", Management Decision, Vol. 46 No. 2, pp. 310-329.

Exline, J.J. and Hill, P.C. (2012), "Humility: a consistent and robust predictor of generosity", The Journal of Positive Psychology, Vol. 7 No. 3, pp. 208-218.

Eyal, O., Berkovich, I. and Schwartz, T. (2011), "Making the right choices: ethical judgments among educational leaders", Journal of Educational Administration, Vol. 49 No. 4, pp. 396-413.

Faris, N. and Abdalla, M. (2018), "Leadership in Islam based on primary sources", Leadership in Islam, Palgrave Macmillan, Cham. pp. 9-25.

Ferrell, O.C. and Gresham, L.G. (1985), "A contingency framework for understanding ethical decision making in marketing", Journal of Marketing, Vol. 49 No. 3, pp. 87-96.

Fornell, C. and Larcker, D.F. (1981), "Structural equation models with unobservable variables and measurement error: algebra and statistics", Journal of Marketing Research, Vol. 18 No. 3, pp. 382-388.

García-Morales, V.J., Lloréns-Montes, F.J. and Verdú-Jover, A.J. (2008), “The effects of transformational leadership on organizational performance through knowledge and innovation", British Journal of Management, Vol. 19 No. 4, pp. 299-319.

Goleman, D. (2000), "Leadership that gets results", Harvard Business Review, Vol. 78 No. 2, pp. 78-90.

Griffin, R.W. and Lopez, Y.P. (2005), "Bad behavior in organizations: a review and typology for future research", Journal of Management, Vol. 31 No. 6, pp. 988-1005.

Hackett, R.D. and Wang, G. (2012), "Virtues and leadership: an integrating conceptual framework founded in Aristotelian and Confucian perspectives on virtues", Management Decision, Vol. 50 No. 5, pp. 868-899.

Hair, J.F., Black, W.C., Babin, B.J. and Anderson, R.E. (2010), Multivariate Data Analysis, 7th ed., Prentice Hall, NJ.

Hallinger, P. (1992), "The evolving role of American principals: from managerial to instructional to transformational leaders", Journal of Educational Administration, Vol. 30 No. 3, pp. 35-49.

Hassan, S. (2015), "The influence of national culture on international marketing and consumer behavior in Iraqi Kurdistan, using hofstede's model at individual level”, British Journal of Marketing Studies, Vol. 3 No. 8, pp. 50-78.

Helms, M.M. (2006), "Theory X and theory encyclopedia of management education”, available at: www. enotes.com/managementencyclopedia/theory-x-theory-y \%5 (accessed 6 December 2020). 
RAMJ

16,1

Ho, D.C.W. (2010), "Teacher participation in curriculum and pedagogical decisions: insights into curriculum leadership”, Educational Management Administration and Leadership, Vol. 38 No. 5, pp. 613-624.

Hoy, W.K. and Tarter, C.J. (1993), "A normative theory of participative decision-making in schools", Journal of Educational Administration, Vol. 31 No. 3.

Isenberg, D.J. (1986), “Group polarization: a critical review and meta-analysis”, Journal of Personality and Social Psychology, Vol. 50 No. 6, pp. 1141-1151.

Jacobs, D. and Singell, L. (1993), "Leadership and organizational performance: isolating links between managers and collective success", Social Science Research, Vol. 22 No. 2, pp. 165-189.

Johnson, M.K., Rowatt, W.C. and Petrini, L. (2011), "A new trait on the market: honesty-humility as a unique predictor of job performance ratings", Personality and Individual Differences, Vol. 50 No. 6, pp. 857-862.

Kanungo, R.N. and Conger, J. (1993), "Promoting altruism as a corporate goal", Academy of Management Executive, Vol. 7 No. 3, pp. 37-48.

Keith, J.R. (1996), “A critical perspective on teacher participation in urban schools”, Educational Administration Quarterly, Vol. 32 No. 1, pp. 45-79.

Khine, M.S. (2013), Application of Structural Equation Modeling in Educational Research and Practice, Sense Publishers, Rotterdam.

Khuong, M.N. and Hoang, D.T. (2015), "The effects of leadership styles on employee motivation in auditing companies in Ho Chi Minh City, Vietnam", International Journal of Trade, Economics and Finance, Vol. 6 No. 4, p. 210.

Latham, G.P. and Steele, T.P. (1983), "The motivational effects of participation versus goal setting on performance", Academy of Management Journal, Vol. 26 No. 3, pp. 406-417.

Lenssen, G., Tyson, S., Pickard, S., Bevan, D. and Rok, B. (2009), "Ethical context of the participative leadership model: taking people into account", Corporate Governance: The International Journal of Business in Society, Vol. 9 No. 4, pp. 448-460.

Lindelow, J. (1989), "Participative decision-making”, in Smith, S. and Piele, P. (Eds), School Leadership: Handbook for Excellence, 2nd ed., ERIC Clearinghouse on Educational Management, Eugene, OR, pp. 152-167,

Locke, E.A. and Schweiger, D.M. (1979), "Participation in decision making: one more look", in Staw, B.M. (Ed.), Research in Organizational Behaviour, JAI Press, Greenwich, pp. 265-339.

Lunenburg, F.C. (2011), "Decision-making in organizations", International Journal of Management, Business, and Administration, Vol. 15 No. 1, pp. 1-9.

McCann, E.J. (2011), "Transformational leadership: Increasing institutional effectiveness through participative decision-making”, Available at SSRN 1791924.

McMrry, R. (2003), “The tyranny of groupthink”, Harvard Business Review, Vol. 81, p. 120.

MacKinnon, D.P., Warsi, G. and Dwyer, J.H. (1995), “A simulation study of mediated effect measures”, Multivariate Behavioral Research, Vol. 30 No. 1, pp. 41-62.

Manning, G. and Curtis, K. (2009), The Art of Leadership, 3rd ed., McGraw-Hill, New York, NY.

Marsh, H.W. and Hocevar, D. (1988), "A new, more powerful approach to multitrait-multimethod analyses: application of second-order confirmatory factor analysis", Journal of Applied Psychology, Vol. 73 No. 1, p. 107.

Melé, D. (2005), "Ethical education in accounting: integrating rules, values and virtues", Journal of Business Ethics, Vol. 57 No. 1, pp. 97-109.

Morales-Sánchez, R. and Cabello-Medina, C. (2013), "The role of four universal moral competencies in ethical decision-making", Journal of Business Ethics, Vol. 116 No. 4, pp. 717-734. 
Mumford, M.D., Zaccaro, S.J., Harding, F.D., Jacobs, T.O. and Fleishman, E.A. (2000), "Leadership skills for a changing world: solving complex social problems", The Leadership Quarterly, Vol. 11 No. 1, pp. 11-35.

Ndiku, J., Simiyu, A. and Achoka, S.K. (2009), "Improving decision making in schools through teacher participation”, Educational Research and Reviews, Vol. 4 No. 8, p. 391.

Leadership and

performance links

Ngambi, H.C. (2011), “The relationship between leadership and employee morale in higher education”, African Journal of Business Management, Vol. 5 No. 3, p. 762.

Noah, Y. (2008), "A study of worker participation in management decision making within selected establishments in Lagos", Journal of Social Sciences, Vol. 17 No. 1, pp. 31-39.

Noddings, N. (1984), Caring: A Feminine Approach to Ethics and Moral Education, University of CA Press, Berkeley, CA.

Olobatuyi, M.E. (2006), A User's Guide to Path Analysis, University Press of America.

Osman-Gani, A.M., Hashim, J. and Ismail, Y. (2013), "Establishing linkages between religiosity and spirituality on employee performance", Employee Relations, Vol. 35 No. 4, pp. 360-376.

Owens, B.P. (2009), "The utility of humility in organizations: establishing construct, nomological, and predictive validity", Academy of Management Proceedings, Vol. 2009, No.1, Academy of Management, Briarcliff Manor, New York, NY 10510, pp. 1-6.

Owens, B.P. and Hekman, D.R. (2016), "How does leader humility influence team performance? Exploring the mechanisms of contagion and collective promotion focus", Academy of Management Journal, Vol. 59 No. 3, pp. 1088-1111.

Paauwe, J. (2004), HRM and Performance: Unique Approaches for Achieving Long-Term Viability, Oxford University, Oxford.

Palanski, M.E. and Yammarino, F.J. (2007), "Integrity and leadership: clearing the conceptual confusion”, European Management Journal, Vol. 25 No. 3, pp. 171-184.

Palanski, M.E., Cullen, K.L., Gentry, W.A. and Nichols, C.M. (2015), "Virtuous leadership: exploring the effects of leader courage and behavioral integrity on leader performance and image", Journal of Business Ethics, Vol. 132 No. 2, pp. 297-310.

Pathak, A. and Rana, S. (2019), "Managing job related attitudes through employee participation: an empirical analysis", International Journal of Scientific Research and Review, Vol. 7 No. 2, pp. 562-573.

Probst, T.M. (2005), "Considering the negative effects of job insecurity through participative decision making: lessons from the demand-control model", Journal of Occupational Health Psychology, Vol. 10 No. 4, pp. 320-329.

Rarick, C., Winter, G., Barczyk, C. and Merkt, E. (2014), "Iraqi and Kurdish cultural values in the semiautonomous state of Kurdistan", Global Journal of Management and Business Research, Vol. 14 No. 3.

Reave, L. (2005), "Spiritual values and practices related to leadership effectiveness", The Leadership Quarterly, Vol. 16 No. 5, pp. 655-687.

Redman, J.A. (1992), "Nine creative brainstorming techniques”, Quality Digest, pp. 50-51.

Richard, P.J., Devinney, T.M., Yip, G.S. and Johnson, G. (2009), "Measuring organizational performance: towards methodological best practice”, Journal of Management, Vol. 35 No. 3, pp. 718-804.

Riggio, R.E., Zhu, W., Reina, C. and Maroosis, J.A. (2010), "Virtue-based measurement of ethical leadership: the leadership virtues questionnaire”, Consulting Psychology Journal: Practice and Research, Vol. 62 No. 4, p. 235.

Robbins, S.P. and Coulter, M. (2013), Management, 11th ed., Pearson.

Roth, P.L., Lydia, L.F. and Switzer, F.S. (1995), "Nominal group technique - an aid for implementing TQM", CPA Journal, pp. 68-69. 
RAMJ

16,1

Rowe, G. and Wright, G. (1999), "The Delphi technique as a forecasting tool: issues and analysis", International Journal of Forecasting, Vol. 15 No. 4, pp. 353-375.

Sagie, A. (1994), "Participative decision making and performance: a moderator analysis", The Journal of Applied Behavioral Science, Vol. 30 No. 2, pp. 227-246.

Sagie, A. and Aycan, Z. (2003), "A cross-cultural analysis of participative decision-making in organizations", Human Relations, Vol. 56 No. 4, pp. 453-473.

Sagie, A., Elizur, D. and Koslowsky, M. (1995), "Decision type, participative decision-making (PDM) and organizational behaviour: an experimental simulation”, Human Performance, Vol. 8 No. 2 , pp. 81-94.

Shaed, M.M., Ishak, S. and Ramli, Z. (2015), "Employees' participation in decision-making (PDM): a literature survey", Malaysian Journal of Society and Space, Vol. 11 No. 13, pp. 142-155.

Shapiro, J.P. and Stefkovich, J.A. (2016), Ethical Leadership and Decision Making in Education: Applying Theoretical Perspectives to Complex Dilemmas, 4th ed., Routledge, New York, NY.

Silla, I., Gracia, F.J. and Peiró, J.M. (2020), "Upward voice: participative decision making, trust in leadership and safety climate matter", Sustainability, Vol. 12 No. 9, p. 3672.

Smylie, M.A., Lazarus, V. and Brownlee-Conyers, J. (1996), "Instructional outcomes of school based participative decision making”, Educational Evaluation and Policy Analysis, Vol. 18 No. 3, pp. 181-198.

Sofijanova, E. and Chatleska, V.Z. (2013), "Employee involvement and organizational performance: evidence from manufacturing sector in Republic of Macedonia”, Trakia Journal of Science, Vol. 11 No. 1, pp. 31-36.

Somech, A. (2002), "Participative decision-making in schools: a mediating-moderating analytical framework for understanding school and teacher outcomes", Educational Administration Quarterly, Vol. 46 No. 2, pp. 174-209.

Sosik, J.J., Gentry, W.A. and Chun, J.U. (2012), "The value of virtue in the upper echelons: a multisource examination of executive character strengths and performance", The Leadership Quarterly, Vol. 23 No. 3, pp. 367-382.

Sosik, J.J., Chun, J.U., Ete, Z., Arenas, F.J. and Scherer, J.A. (2019), "Self-control puts character into action: examining how leader character strengths and ethical leadership relate to leader outcomes", Journal of Business Ethics, Vol. 160 No. 3, pp. 765-781.

Steel, R.P. and Mento, A.J. (1987), "The participation-performance controversy reconsidered: subordinate competence as a mitigating factor", Group and Organization Studies, Vol. 12 No. 4, pp. 411-423.

Stoner, J.A. (1968), "Risky and cautious shifts in group decisions: the influence of widely held values", Journal of Experimental Social Psychology, Vol. 4 No. 4, pp. 442-459.

Straub, D., Boudreau, M.C. and Gefen, D. (2004), "Validation guidelines for is positivist research", Communications of the Association for Information Systems, Vol. 13 No. 1, p. 24.

Subbulakshmi, S., Nagarajan, S.K. and Felix, A.J.W. (2014), "A study on participation in decisionmaking among members of quality circle in manufacturing companies", Iosr Journal of Business and Management, Vol. 16 No. 4, pp. 25-31.

Sukirno, D.S. and Siengthai, S. (2011), "Does participative decision-making affect lecturer performance in higher education?", International Journal of Educational Management, Vol. 25 No. 5, pp. 494-508.

Tangney, J.P. (2000), "Humility: theoretical perspectives, empirical findings and directions for future research", Journal of Social and Clinical Psychology, Vol. 19 No. 1, pp. 70-82.

Tarim, M., Zaim, H. and Torun, Y. (2014), "Is ahlaki uygulamalarinin hastane performansina etkisi: kamu hastaneleri üzerine bir saha çalismasi”, Iş Ahlakı Dergisi, Vol. 7 No. 2, p. 121. 
Trevino, L.K., Brown, M. and Hartman, L.P. (2003), "A qualitative investigation of perceived executive ethical leadership: perceptions from inside and outside the executive suite", Human Relations, Vol. 56 No. 1, pp. 5-37.

Trevino, L.K., Hartman, L.P. and Brown, M. (2000), "Moral person and moral manager: how executives develop a reputation for ethical leadership", California Management Review, Vol. 42 No. 4, pp. 128-142.

Valverde-Moreno, M., Torres-Jimenez, M. and Lucia-Casademunt, A.M. (2020), "Participative decisionmaking amongst employees in a cross-cultural employment setting: evidence from 31 European countries", European Journal of Training and Development, Vol. 45 No. 1, doi: 10.1108/EJTD-102019-0184.

Vangrieken, K., Dochy, F. and Raes, E. (2016), “Team learning in teacher teams: team entitativity as a bridge between teams-in-theory and teams-in-practice", European Journal of Psychology of Education, Vol. 31 No. 3, pp. 275-298.

Venkatraman, N. and Ramanujam, V. (1986), "Measurement of business performance in strategy research: a comparison of approaches", Academy of Management Review, Vol. 11 No. 4, pp. 801-814.

Wagner, J.A. III, (1994), "Participation's effects on performance and satisfaction: a reconsideration of research evidence", Academy of Management Review, Vol. 19 No. 2, pp. 312-330.

Wainaina, L.M., Iravo, M. and Waititu, A. (2014), "Effect of employee participation in decision-making on the organizational commitment amongst academic staff in the private and public universities in Kenya", International Journal of Advanced Research in Management and Social Science, Vol. 3 No. 12, pp. 131-142.

Wong, Y.Y., Chow, I.H.S., Lau, V.P. and Gong, Y. (2018), "Benefits of team participative decision making and its potential to affect individual creativity", Journal of Applied Social Psychology, Vol. 48 No. 7, pp. 369-376.

Woodruff, E., Van Tongeren, D.R., McElroy, S., Davis, D.E. and Hook, J.N. (2014), "Humility and religion: benefits, difficulties, and a model of religious tolerance", Religion and Spirituality across Cultures, Springer, Dordrecht, pp. 271-285.

Yates, L.A. (2014), "Exploring the relationship of ethical leadership with job satisfaction, organizational commitment, and organizational citizenship behavior", The Journal of Values-Based Leadership, Vol. 7, pp. 14-21.

Yıldırım, I., Akan, D. and Yalçin, S. (2019), "Participation in decision-making process as a predictor of organizational cynicism at schools", Online Submission, Vol. 8 No. 2, pp. 487-506.

Zacher, H., Pearce, L.K., Rooney, D. and McKenna, B. (2014), "Leaders' personal wisdom and leadermember exchange quality: the role of individualized consideration", Journal of Business Ethics, Vol. 121 No. 2, pp. 171-187.

Zaim, H., Demir, A. and Budur, T. (2020), "Ethical leadership, effectiveness and team performance: an Islamic perspective", Middle East Journal of Management, doi: 10.1504/MEJM.2021.10033656.

\section{Further reading}

Cochran, W.G. (1977), Sampling Techniques, 3rd ed., Wiley, New York, NY.

Krejcie, R.V. and Morgan, D.W. (1970), "Determining sample size for research activities”, Educational and Psychological Measurement, Vol. 30 No. 3, pp. 607-610. 


\section{RAM \\ 16,1}

\section{Appendix}

PDM

PDM1

My manager makes decisions via considering the viewpoints of group members

PDM2 My manager considers the ideas of group members in a discussion

84

PDM3 My manager seeks an agreed problem solution between group members in decision-making

My manager treats subordinates fairly

My manager equally employs the rules for everyone

My manager acts fairly regarding the decisions on

subordinates (Dropped)

My manager allocates the workload fairly

My manager makes and executes brave decisions

My manager does not avoid taking risk

My manager stands behind his brave decisions

M8 My manager is brave enough to take full responsibility of

M8 My manager is brave enough to take full responsibility of

M9 I believe that my manager is an honest man

M10 My manager emphasizes truthfulness

M11 My manager keeps his promises

M12 My manager does not cheat people (Dropped)

K

K1 My manager has technical knowledge about his job

K2 My manager has intellectual capacity

K3 My manager is knowledgeable to make right decisions

K4 My manager has the ability to use right knowledge at right time

K5 My manager has sufficient interpersonal skills

K6

K7

K8

K9

My manager helps us to see "the big picture."

I trust my manager's foresight

I trust my manager's vision

My manager emphasizes the importance of shared vision

A

A1

A2

A3

A4

A5

A6

A7

A8

$L P$

Table A1.

LP2

PDM, EL, LP
My manager can always control his/her temper

My manager warns his/her subordinates kindly when they make a mistake

My manager is a tolerant person

I think my manager is a polite person

I think my manager is a modest person

My manager is arrogant. (Dropped)

My manager thinks that he/she knows everything himself. (Dropped)

My manager appreciates others' opinions

I believe that my manager is an effective leader

I believe that my manager has sufficient leadership skills

I am willing to work with my manager for a long time

My manager inspires his/her subordinates

$\begin{array}{lllllll}1 & 2 & 3 & 4 & 5 & 6 & 7 \\ 1 & 2 & 3 & 4 & 5 & 6 & 7 \\ 1 & 2 & 3 & 4 & 5 & 6 & 7\end{array}$




\begin{abstract}
About the authors
Dr Nuri Gökhan Torlak studied Industrial Relations and Economics at Istanbul University from 1983 to 1987, where he received his BA. Then, he achieved his MA in Management Systems at Hull University in 1991 and his $\mathrm{PhD}$ in Management Systems at University of Lincolnshire and Humberside in 1999. Torlak spent his academic life teaching at Bilgi University from 2001 to 2002 and Fatih University since 2002 where he chaired Department of Management from 2004 to 2008. He became Associate Professor in 2010 and Full Professor in 2015 in the area of Management and Organization. He currently works as a senior lecturer at Doğuş University, Department of Business Administration. He supervised twenty MA students and one $\mathrm{PhD}$ student to successful completion. He published numerous articles and books in peer-reviewed and prestigious national and international journals, delivered conference papers and undertaken consultancy engagements and EU projects. His research interests include the applications of systems methodologies, methods and techniques in the resolution of methodological, managerial and organizational problems. Nuri Gökhan Torlak is the corresponding author and can be contacted at: ntorlak@dogus.edu.tr

$\mathrm{Dr}$ Ahmet Demir achieved his $\mathrm{PhD}$ in total quality management at International Black Sea University, Tbilisi, Georgia in 2015. He has been lecturing at Ishik University, Kurdistan Region of Iraq for eight years.

Mr Taylan Budur had a MA degree from Fatih University, Istanbul, Turkey, in 2013. He is interested in management and organization field. $\mathrm{He}$ is currently a $\mathrm{PhD}$ candidate at Burch University, Bosnia. He has been lecturing at Ishik University since 2016.
\end{abstract}

For instructions on how to order reprints of this article, please visit our website: www.emeraldgrouppublishing.com/licensing/reprints.htm Or contact us for further details: permissions@emeraldinsight.com 